\title{
Some Advice on Tourism Management System Reform
}

\author{
Zhao Ying Zhong Xiaodong \\ Tourism and Civil Aviation Management Institute, Haikou College of Economics, Haikou, China, \\ 571127
}

Key words: Tourism system management; Reform; Tourism industry

Abstract: Tourism system reform in large level is helpful to promote the development of tourism industry and the market economy in our country. At present, our country's tourism administration has some prominent problems, and it is necessary to formulate the corresponding reform measures. The paper mainly discusses the problem status of the tourism administration and formulates reform countermeasures.

Tourism is the third largest industry in China, and also a kind of industry emerged after reform and opening up. The development of a regional tourism helps to promote the region's economic development and social progress. In general, the tourism industry in our country has experienced three stages of development, and each stage of the development promotes tourism in one step forward. Tourism industry and the market economy system in China are in very close relationship. The development of tourism industry, at the same time also contributes to the change of the market economy system in our country. There are some problems in current tourism management system, and it is necessary to solve them in time. How to further improve tourism management department function, innovate management system, coordinate tourism enterprises' efficient and orderly operation are important problems need to be solved [1]. Innovate tourism economy system in our country, at the same time; strengthen the propaganda to promote the development of China's tourism industry.

\section{THE PRESENT SITUATION AND PROBLEMS IN TOURISM MANAGEMENT}

The current tourism management system in our country is government-dominated and has a big problem, which limits the further development of tourism industry [2]. Tourism administration has no standard structure setting, and level functions are not clear. At present, tourism management institutions established by the government do not conform to the tourism administrative department responsibilities in many places, which not only can't meet the needs of tourism development, at the same time, it does not meet the need of law administration, let alone achieve more perfect and innovated tourism management system in our country. Tourism management institutions were set up corresponding departments from the state to local places with good momentum, however, there is no perfect and reasonable management institution, and have not reached the coverage that should be reached. Tourism administrative management is out of control. Our current system of tourism management departments is intersected. The tourist resources are respectively managed by different administrative departments. Tourism enterprises respectively belong to different departments, such as different types of scenic spots and cultural relics resources should be managed by corresponding tourism, ocean and departments. Tourism supervision and management system need to be strengthened. There is tourism management supervision vacancy phenomenon in our country. Tourism resources and enterprises belong to different department management in vertical and horizontal management. On the vertical management, supervision system of administrative department cannot effectively manage the administrative department at a lower level; in horizontal management, due to different types of supervision mechanism is not reasonable and has no clear labor division, leading to some problems, supervision loopholes, and shuffle phenomenon happens quite often. At present, under the jurisdiction of China tourism covered area is larger, such as tourist hotels association and restaurant association, however, these just stay on the surface level of industrial development planning, and cannot effectively monitor industry management and the employees work; Part of county areas appear even the industry association, which is unable to effectively implement the supervision of the tourism industry. 


\section{THE COUNTERMEASURES}

\section{A. Establish a diversified management main body}

As the reform further deepening, tourism administrative system reform is actively explored which adapt to the tourism development around the country [3]. China's tourism management system should be a diversified management mode, involving industry association and general public, tourism enterprises, tourism administrative department, etc. Tourism administrative departments perfect the tourism administrative institutions, and clear management function. First of all, the tourism management system builds the high level and high power of national tourism management institutions, such as national tourism administration: tourism management committee in our country, which mainly relate to the administration of state administration of cultural heritage, tourism hotel catering and multiple business institutions, the unified administration of tourism work throughout the country. Secondly, tourism management system improves local tourism management organization. Some provinces study advanced experience in the reform of tourism management system, and make the built system conforms to this region's tourism characteristic development; set up tourism management committee, the middle service sector to connect national and local tourism management agencies, which is the highest policy-making body and tourism comprehensive coordination department, and give full play to its function. Tourism administrative departments should develop tourism enterprises for its better development. Under socialist market economic system, enterprise is the main body of market. Government tourism enterprises push the enterprise to the market completely, and carry on the macroeconomic regulation and control, usually, to direct intervene enterprise microscopic management. On innovation development idea, pay attention to deal with the relationship between market and government. Fuse tourism development into the new construction of "four modernization"; make tourism industry positioning in people-oriented. On accelerate transformation of mode development, propel tourism products transformation toward the direction of sightseeing, holiday and leisure; Transform tourism development to intensive change which can help to promote tourism service implementation of quality services. Objective assessment effectively plays the role of their baton, "Opinion" does not again put forward tourist trips quantitative index, but highlights the quality indicators, such as trips and tourism consumption per capita.

Government should bear the supervisors and coordination of industry, guide and regulate the development of tourism, but not replace the role of tourism enterprises in the market, so as to make the tourism industry better play resource allocation function. Tourism administrative departments improve tourism industry association, and effectively play a role of industry associations. At the same time in the development of market economy in our country, tourism development has its particular role in the transformation of government functions, and need to give full play of tourism industry association role, which is the necessity of tourism management system reform in our country. Under the condition of new forms, state and local governments at various levels should require travel sectors in combination with the actual development situation, to establish related industry association. Make the travel industry association independent of the government administrative agencies, control all their income and expenditure management, promote the healthy development of tourism industry in our country, and contribute to the follow-up smooth development. Tourist city departments should build a perfect system of public participation. Tourism management should be implemented in public management. Management subject arouses the public, in view of the different levels tourism management department tourism strategy and development planning enact rules and regulations and policy measures, and puts forward suggestions and opinions. Tourism enterprises and tourism management departments evaluate matters in various supervision power, rules and regulations and policy measures, and can make decisions during the matter and afterwards.

\section{$B$. The systematic adjustment of industrial structure}

Tourism administration departments should strengthen tourism resource development and regional integration, make tourism products engineering. Make market demand as the guidance, and locate center in product development, tourism project construction as the key, practice high-quality goods 
strategy, and form highlight key point plane linkage development strategy development pattern. Promote "land and sea link" interaction pattern tourism development. Tourism administrative department should improve its proportion of tourism commodity output, and entertainment industry. For inadequate consumption of entertainment and not high shopping cost, in the direction of marketization development, advocate and support the development of the society to speed up tourist entertainment and tourism commodities. Strengthen the planning, classify guidance, and reveal features. Key development regional characteristics and tourism commodities are the characteristics to attract tourists. Expand economic scale for greater income. Tourism administrative departments should reasonably control the hotel number, and optimize hotel type. At present, the hotel industry appears a lot of high-grade hotels. They have a larger size, numerous quantity, while cheap hotels are on a smaller scale, however, hotel industry, according to tourism customer market structure and demand, should adjust and optimize the structure of tourist accommodation facilities and guidance resort and tourist hotel should develop towards multi-level with diversified development and social accommodation facilities should be brought into the tourism management. Tourism administrative departments should develop characteristic catering, and create food and beverage brands. Introduce and promote all kinds of food which can meet the requirements of different types of tourists, encourage and develop local flavor snacks, hold cooking skills competition and characteristics snacks campaign, realize the combination of citizens and tourists and experts, and shape catering chains conforming to the characteristics of local tourism. Tourism administrative departments should grasp the historical opportunity of the financial crisis; effectively implement incentive measures issued by the government, and advance travel upgrade structure. Through national industrial policies, guide travel towards network toward the direction of specialization and scale, promote the electronic commerce development of tourism industry, and the development of new tourism services, such as online travel agencies. Take advantage of sales network to achieve cross-regional franchising development. Tourism industry structure provides support for the whole tourism management system, and reasonable industrial structure can better balance development between industrial structure, and make local tourism structure in balance. The government should strengthen the construction of local infrastructure. When tourists travel there, provide them with high quality enjoyment, and promote the local tourism destination image as a whole.

C. Follow the law of tourism development, and effectively coordinate internal management

Tourism industry occupies an important position in national economy development. In accordance with the laws of tourism development and the market, the innovation of the management system is put forward, which mainly manifested in the following aspects: market orientation, international practice and sustainable development, etc. Tourism development runs under the condition of across regions and across national borders. Based on international standards, according to international practice, create conditions for tourism market to promote better development. Tourism administrative departments should attach importance to comprehensive coordination. Tourism is a strong correlation industry, involving many fields, such as shopping, entertainment and tourism scenic spot, and it is also a relatively independent industry. Tourism administrative department should emphasize functional transformation and liability classification of management function departments. Tourism is a comprehensive industry, which contains relevant functional departments, such as civil aviation, transport and tourism, etc. To build mutual restrict administrative mode in tourism management department, promote fair competition. The tourism development in many parts have the emergence of monopoly situation, however, the reasons for this situation is that there is no management system which can mutual separate powers, and check and balance effectively. To ensure that each department achieve balance in tourism development, we not only need supervision system, at the same time also need evaluation system. In all mutual restriction of rights, establish a perfect management mode. This is the basic principle uphold in most areas tourism development. Improper competition seriously influence the development of local tourism industry, and the government should give reasonable management. In the face of unfair competition, reflect this situation to the local tourism, with rational allocation of tourism resources, ensure that every one can appropriately manage surrounding tourism industry. While promoting the development of 
tourist industry, protect the interests of tourists themselves.

D. Carry out paid system, and set up regional tourism maintenance team

Hugh annual paid leave system should be in local governments agenda for labor inspection and provide important guarantee of the rights and interests of employees. Under the condition of total amount of practice, based on reality, adjust holiday arrangements. Local governments should attach importance to strengthen the construction of tourism infrastructure. The central government should increase tourism infrastructure support in some areas such as concentrated destitute areas, key scenic area and central and western regions. Under the condition of new forms, the government will continue to provide fiscal and financial policy support, make planning, carry out personnel training and provide support for public service system construction. Second, carry on the innovative tourism land management system, to constantly improve and guide tourism supply structural adjustment, promote the differentiation of land management, make effective progressive combination, elaborate tourism projects development in abandoned mines, dump slope, desertification land, and provide support. Tourism administrative system reform should implement the strategy of "talents facilitate tourism, and science aid tourism", perfect the various mechanisms. To achieve a region's tourism industry innovation, we need the government's macro management, and set up different types of system. Maintenance team setting in local tourism can promote the development of local tourism from different aspects, and virtually form a kind of consciousness and discipline industry.

\section{CONCLUSION}

The tourism in our country has been developed for many years. Although our country's tourism management system unceasingly reforms, it also has obtained certain achievements [4]. The tourism management administrative departments cooperate with each other. According to practical problems, as the tangut, dare to break through innovation, promote reform and development of tourism, make project work the responsibility for some departments. Reforms should be carried out around the masses. Comprehensively deepen reform and tourism combined daily work, promote the reform, and realize the scientific development of tourism industry. National tourism administration system has a larger development space, which requires the local government and the relevant personnel to cooperate effectively. Of course, the reform of the tourism system needs a certain time, at the right time implement a system reform. From the point of long-term development, the development of tourism in our country will enter a new stage.

\section{REFERENCES}

[1] Zhu Yongmeng. Zhejiang Marine tourism management system research from industrial convergence perspective [D]. Zhejiang Sea Institute, 2013.

[2] Wang Meiyun. The evolution and reform path research of tourism management system [J]. Journal of Commercial Age, 2013, (14) : 100-101.

[3] Hu Fusheng. Local tourism administrative management system reform should speed up the transformation of function [J]. Journal of Travel, 2014, (9) : 7-9.

[4] XinYu. Tourism management system reform in China [J]. Journal of Travel Survey (Second Half), 2013, (9) : 58-59. 